\title{
Effects of Selective Deletion of Tyrosine Hydroxylase from Kisspeptin Cells on Puberty and Reproduction in Male and Female Mice
}

\author{
Shannon B. Z. Stephens, ${ }^{-}$Melvin L. Rouse, ${ }^{\circledR}$ Kristen P. Tolson, ${ }^{\circledR}$ Reanna B. Liaw, Ruby A. Parra, Navi \\ Chahal, and Alexander S. Kauffman
}

DOI:http://dx.doi.org/10.1523/ENEURO.0150-17.2017

Department of Reproductive Medicine, University of California, San Diego La Jolla, CA 92093

\begin{abstract}
The neuropeptide kisspeptin, encoded by Kiss1, regulates reproduction by stimulating GnRH secretion. Kiss1syntheizing neurons reside primarily in the hypothalamic anteroventral periventricular (AVPV/PeN) and arcuate (ARC) nuclei. AVPV/PeN Kiss1 neurons are sexually dimorphic, with females expressing more Kiss1 than males, and participate in estradiol $\left(E_{2}\right)$-induced positive feedback control of $\mathrm{GnRH}$ secretion. In mice, most AVPV/PeN Kiss1 cells coexpress tyrosine hydroxylase $(\mathrm{TH})$, the rate-limiting enzyme in catecholamine synthesis (in this case, dopamine). Dopamine treatment can inhibit $\mathrm{GnRH}$ neurons, but the function of dopamine signaling arising specifically from AVPV/PeN Kiss1 cells is unknown. We generated a novel TH flox mouse and used Cre-Lox technology to selectively ablate $T H$ specifically from Kiss 1 cells. We then examined the effects of selective $T H$ knock-out on puberty and reproduction in both sexes. In control mice, $90 \%$ of AVPV/PeN Kiss1 neurons coexpressed TH, whereas in mice lacking $T H$ exclusively in Kiss 1 cells (termed Kiss THKOs), TH was successfully absent from virtually all Kiss 1 cells. Despite this absence of $T H$, both female and male Kiss THKOs displayed normal body weights, puberty onset, and basal gonadotropin levels in adulthood, although testosterone (T) was significantly elevated in adult male Kiss THKOs. The $\mathrm{E}_{2}$-induced LH surge was unaffected in Kiss THKO females, and neuronal activation status of kisspeptin and GnRH cells was also normal. Supporting this, fertility and fecundity were normal in Kiss THKOs of both sexes. Thus, despite high colocalization of $T H$ and Kiss 1 in the AVPV/PeN, dopamine produced in these cells is not required for puberty or reproduction, and its function remains unknown.
\end{abstract}

Key words: dopamine; GnRH; Kiss1; kisspeptin; puberty; reproduction

\section{Significance Statement}

Kisspeptin promotes reproduction, and kisspeptin neurons in the hypothalamic anteroventral periventricular (AVPV/PeN) nucleus mediate estradiol $\left(\mathrm{E}_{2}\right)$-positive feedback control of $\mathrm{GnRH}$ secretion. Dopamine treatment can inhibit GnRH neurons, and most AVPV/PeN kisspeptin cells are also dopaminergic (coexpress tyrosine hydroxylase, $\mathrm{TH}$ ), but it is unknown if dopamine specifically in AVPV/PeN kisspeptin cells regulates GnRH neurons. Using Cre-Lox technology, we determined that the selective knock-out of $T H$ in kisspeptin cells surprisingly has no effect on puberty, reproductive hormones, or fertility. Thus, despite being highly coexpressed, dopamine in kisspeptin cells is not required for reproduction. Dopamine in these cells likely serves other yet-to-be-identified roles, perhaps unrelated to reproductive neuroendocrinology.

Received May 3, 2017; accepted June 9, 2017; First published June 15, 2017. The authors declare no competing financial interests.

Author contributions: S.B.Z.S., M.L.R., K.P.T., and A.S.K. designed research; S.B.Z.S., M.L.R., K.P.T., R.B.L., R.A.P., N.C., and A.S.K. performed research; S.B.Z.S., M.L.R., R.B.L., and A.S.K. analyzed data; S.B.Z.S. and A.S.K. wrote the paper. 


\section{Introduction}

The neuropeptide kisspeptin, encoded by the Kiss 1 gene, stimulates $\mathrm{GnRH}$ release and, thus, is necessary for reproduction (de Roux et al., 2003; Seminara et al., 2003; Gottsch et al., 2004; Lapatto et al., 2007; d'Anglemont de Tassigny et al., 2008; Topaloglu et al., 2012). There are two primary hypothalamic populations of Kiss1 neurons: in the anteroventral periventricular-rostral periventricular continuum (AVPV/PeN) and arcuate (ARC) nuclei (Gottsch et al., 2004; Clarkson and Herbison, 2006). Kiss1 neurons in the ARC are likely involved in pulsatile gonadotropin secretion and steroid hormone negative feedback, as gonadectomy (GDX) increases ARC Kiss1 levels, while testosterone $(T)$ or estradiol $\left(E_{2}\right)$ treatment suppresses ARC Kiss1 expression (Smith et al., 2005a, b; Kauffman et al., 2007). In contrast to the ARC, in the AVPV/PeN, GDX decreases Kiss 1 expression, while $E_{2}$ treatment increases Kiss1 expression (Smith et al., 2005a, b; Kauffman et al., 2007). Thus, Kiss 1 in the AVPV/PeN is thought to be involved in mediating $\mathrm{E}_{2}$-positive feedback, which triggers the preovulatory LH surge. Supporting this hypothesis, Kiss 1 expression in greater in females than males (males do not show an LH surge), Kiss 1 neurons in the AVPV/PeN express ER $\alpha$ and show increased neuronal activation exclusively during the LH surge, and Kiss $1 \mathrm{KO}$ and Kiss1r KO mice cannot exhibit an LH surge even with exogenous $\mathrm{E}_{2}$ treatment (Smith et al., 2005a, 2006; Kauffman et al., 2007; Clarkson et al., 2008; Robertson et al., 2009; Dror et al., 2013).

In addition to the sexually dimorphic population of Kiss 1 neurons, the AVPV/PeN also contains a sexually dimorphic population of tyrosine hydroxylase (TH) neurons, with females having more TH cells than males (Simerly et al., 1985). TH is the rate-limiting enzyme in catecholamine synthesis, and AVPV/PeN TH neurons are known to be dopaminergic (Simerly et al., 1985; Scott et al., 2015). These dopaminergic AVPV neurons have both direct and indirect projections to GnRH neurons, indicating AVPVderived dopamine may influence reproduction (Clarkson and Herbison, 2011; Kumar et al., 2015). However, there is conflicting evidence as to whether dopamine stimulates or inhibits $\mathrm{GnRH}$ release. Application of dopamine to medial basal hypothalamic explants increased GnRH release (Rotsztejn et al., 1977; Jarjour et al., 1986). How-

This work was supported by NSF Grant IOS-1457226 and NIH Grant R01 HD082567, P50 HD012303 (University of California, San Diego), and P50 HD28934 (University of Virginia). S.B.Z.S. was supported by NIH Grants F32 HD088060 and T32 HD007203.

Acknowledgements: We thank Dr. Carol Elias (University of Michigan) for the generous gift of the Kiss-Cre mice. We also thank Art Nasamran for technical and experimental support.

Correspondence should be addressed to Alexander S. Kauffman, Department of Reproductive Medicine, Leichtag Building, Room 3A-15, University of California, San Diego, 9500 Gilman Drive, \#0674, La Jolla, CA 92093, E-mail: akauffman@ucsd.edu.

DOI:http://dx.doi.org/10.1523/ENEURO.0150-17.2017

Copyright (C) 2017 Stephens et al.

This is an open-access article distributed under the terms of the Creative Commons Attribution 4.0 International license, which permits unrestricted use, distribution and reproduction in any medium provided that the original work is properly attributed. ever, intracerebroventricular injections of dopamine antagonists increased the amount of $\mathrm{GnRH}$ and $\mathrm{LH}$ release during a PMSG-induced GnRH surge, which suggests that dopamine inhibits $\mathrm{GnRH}$ release (Sarkar and Fink, 1981). Supporting an inhibitory role of dopamine on $\mathrm{GnRH}$, electrophysiology experiments demonstrate that dopamine can inhibit the firing of GnRH directly, via D1 and D2 receptors (Liu and Herbison, 2013).

Interestingly, in mice, the vast majority of AVPV/PeN Kiss1 neurons are dopaminergic and coexpress $T H$ (Semaan et al., 2010), whereas TH is not localized with kisspeptin in the ARC region (Szawka et al., 2010). However, the function of dopamine produced in AVPV/PeN Kiss 1 neurons is currently unknown. As much as $75 \%$ of AVPV/PeN kisspeptin neurons that coexpress $\mathrm{TH}$ send fiber projections that appose $\mathrm{GnRH}$ neurons (Clarkson and Herbison, 2011; Kumar et al., 2015), which suggests that dopamine signaling arising from AVPV/PeN kisspeptin neurons may directly modulate $\mathrm{GnRH}$ secretion, and hence, the neuroendocrine reproductive axis. The current study was designed to assess the effects of selectively deleting $T H$ specifically from Kiss 1 cells on puberty onset, hormone levels, and reproduction. Because kisspeptin neurons in the ARC do not coexpress TH, we hypothesized that any effect of removing $T H$ from Kiss 1 cells on puberty onset and/or reproduction is attributed to AVPV/ PeN Kiss1 neurons, due to the high degree of colocalization of TH and Kiss 1 in the AVPV/PeN. Because dopamine is inhibitory to $\mathrm{GnRH}$ neurons, we predicted that puberty onset may be accelerated and/or fertility or fecundity would be enhanced when dopamine is removed from Kiss 1 cells. Though females express more TH and Kiss 1 in the AVPV/PeN than males, males still express notable numbers of both celltypes in this region and little is known about the role, if any, of AVPV/PeN Kiss 1 or TH in male puberty or reproduction. Therefore, we studied both sexes to identify any possible sex differences in the reproductive function of $T H$ in Kiss 1 cells. To this end, we hypothesized that any observed effects would be sex specific, occurring more in females.

\section{Materials and Methods}

\section{Animals}

We created TH "flox" mice that have loxP sites flanking exons 7-9 of the mouse $\mathrm{TH}$ gene, a region shared by all transcript variants and which, when ablated, disrupts $>50 \%$ of the protein-coding sequence of the TH enzyme. Embryonic stem cells with such loxP sites (Fig. 1A) were obtained from the KOMP repository at UC Davis (Targeting project \#CSD47610; Allele: $\mathrm{Th}^{\mathrm{tm} 1 \mathrm{a}(\mathrm{KOMP}) \mathrm{Wtsi})}$. The stem cells were from a C57BL/6N-A ${ }^{\text {tm1Brd }}$ mouse strain with an Agouti (A/a) coat color. The local university Transgenic Mouse Core injected the TH flox stem cells into blastocyst stage C57BL6 albino embryos. The blastocysts were then implanted into pseudopregnant females, resulting in chimeric pups. Agouti pups were indicative of germline transmission of the TH floxed gene insert. Tail DNA and PCR analysis of the presence of the neomycin cassette confirmed germline transmission of the TH flox insert. Neomycin-positive females were then bred to Flp recom- 
A

TH floxed gene insert

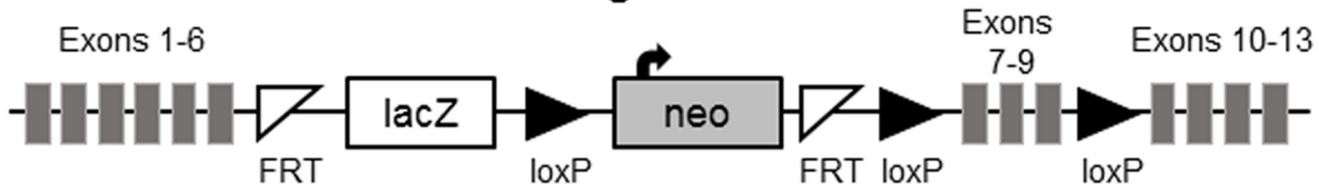

B

TH floxed mouse

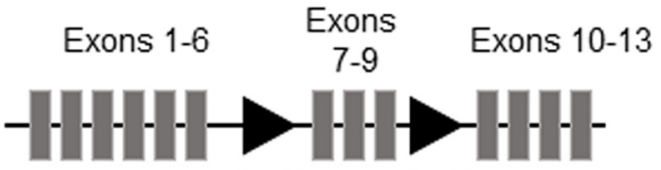

IoxP
IoxP
C

\section{Kiss THKO mouse}

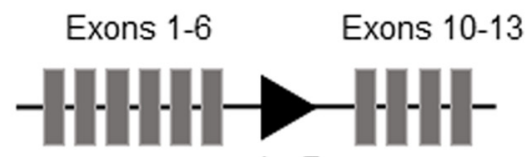

IoxP

D

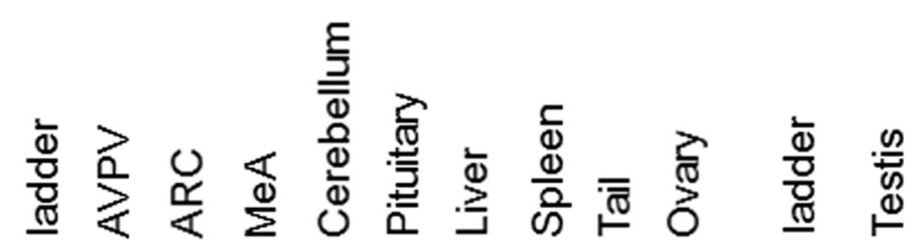

Kiss THKO

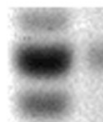

WT
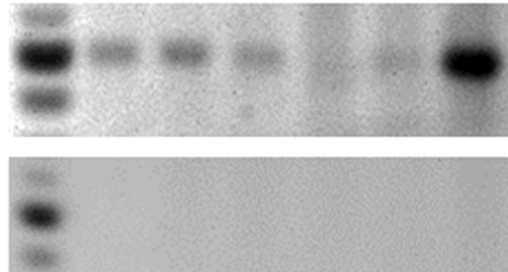

E
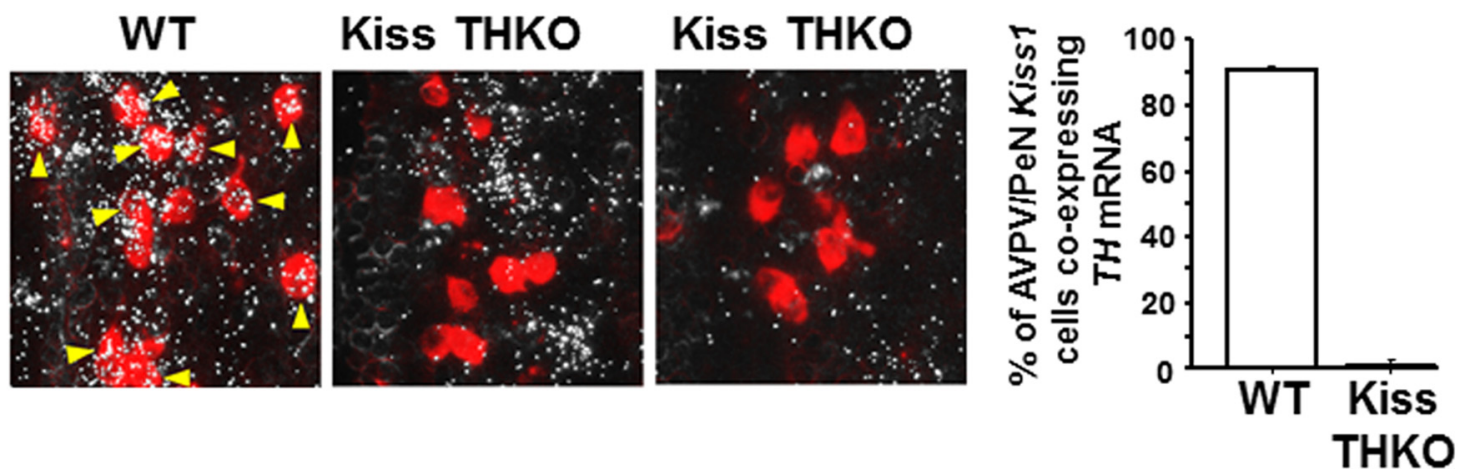

Figure 1. Strategy for knocking TH exclusively out of Kiss1 cells. $\boldsymbol{A}$, The map of the TH "floxed" gene insert in embryonic stem cells (KOMP repository, UC Davis). Presence of the neomycin cassette in PCR analysis was indicative of germline transmission of the $\mathrm{TH}$ flox insert. $\boldsymbol{B}$, Breeding neomycin positive females to Flp recombinase males removed the lacZ and neomycin cassettes and produced TH flox heterozygous mice. These $\mathrm{TH} f \mathrm{fl}$ wt mice were then bred to each other to $\mathrm{produce} \mathrm{TH} \mathrm{fl} / \mathrm{fl}$ mice. C, KissCre mice were bred to TH fl/fl mice to produce KissCre + TH fl/fl mice (Kiss THKOs), which lack exons 7-9 of the TH gene and thus, a functional TH transcript, but only in Kiss1 cells. $\boldsymbol{D}$, Gel image of PCR analysis showing Cre-mediated recombination of $T H$, indicated by the $503 \mathrm{bp}$ band representing successful recombination of the $T H$ gene, only in tissues known to express Kiss1 (AVPV/PeN, ARC, MeA, liver, gonad) and not in other tissues (cerebellum, spleen, tail), which are known to not normally express Kiss1 in Kiss THKO (top) and WT (bottom) mice. E, left, Photomicrograph of TH (silver grains) and Kiss1 (red fluorescence) double label ISH in the AVPV/PeN region of adult female mice. TH mRNA is clearly highly expressed in almost all AVPV/PeN Kiss 1 neurons (examples indicated by yellow arrows) of WT mice but absent in virtually all Kiss 1 cells in Kiss THKO mice. Right, Quantification of the percentage of AVPV/PeN Kiss1 cells coexpressing TH in WT and KissTHKO adult female mice ( $n=4-5 /$ genotype). 
binase males (purchased from The Jackson Laboratory) to remove the lacZ and neomycin cassettes located between the FRT sites (Fig. 1A). Pups of this cross were then genotyped for neomycin, Flp recombinase, and TH flox. Males and females that were neomycin negative/Flp recombinase positive/TH heterozygous were then bred to nonsiblings as adults. From this cross, Flp recombinase negative/TH heterozygous male and female non-siblings were then bred to each other to produce TH $\mathrm{fl} / \mathrm{fl}$ mice (Fig. $1 B)$. TH $\mathrm{fl} / \mathrm{fl}$ mice were determined to be viable, completely fertile, and had normal body size and weights.

Using Cre-Lox technology, we produced mice lacking TH selectively from Kiss 1 cells by mating Kiss 1 Cre mice (provided by Dr. Carol Elias) with our TH flox mice. The heterozygous offspring of this first generation were then backcrossed to TH flox mice, resulting in $\mathrm{Kiss} C r e+\mathrm{TH} \mathrm{fl} / \mathrm{fl}$ mice (termed Kiss THKO; TH specifically knocked out of Kiss 1 cells) and KissCre- TH fl/fl mice (termed WT or controls; TH still present in all cells; Fig. 1C). PCR analysis of tail DNA was used to genotype mice (forward primer: CTGCTGATGGTTGGGTTGG; reverse primer: GCGACATCTCTGAATGACC; WT $=182 \mathrm{bp} ; \mathrm{TH} \mathrm{fl}=400 \mathrm{bp}$ ) and to test for germline recombination (forward primer: GGAGGAAATTGCTACCTGG; reverse primer: CCCTGCAACATACACTTCACC; $W T=1257 \mathrm{bp} ; \mathrm{TH} \mathrm{fl}=1555 \mathrm{bp}$; recombination $=503 \mathrm{bp}$ ) using the following PCR conditions [95 × 5', $(95 \times 30$ ", $53 \times 30$ ", $72 \times 30$ "), repeat $\times$ 30 times, $\left.72 \times 10^{\prime}\right]$. Any mouse with germline recombination was excluded from the experiments. At weaning (three weeks old), mice were housed two to four per cage on a 12/12 h light/dark cycle and given access to food and water ad libitum. All of the experiments were approved by the local Institutional Animal Care and Use Committee.

\section{Confirmation of conditional TH deletion}

To verify Cre-mediated deletion of TH in Kiss 1 cells, micropunches of the AVPV/PeN, ARC, and amygdala, as well as small samples of other peripheral tissues, were collected for DNA isolation. PCR analysis was used to confirm that recombination of the $T H$ gene occurred in just tissues known to express Kiss1, such as the AVPV/ $\mathrm{PeN}, \mathrm{ARC}$, amygdala, liver, and gonad. In addition, in a separate cohort of adult female ovariectomized (OVX), $\mathrm{E}_{2}$-treated (proestrous levels) control and Kiss THKO mice, we used double-label in situ hybridization (ISH; see below) to quantify the degree of TH and Kiss 1 coexpression in the AVPV/PeN (where Kiss1 and TH normally are highly coexpressed). This confirmed that Kiss THKOs lacked TH in AVPV Kiss 1 neurons, unlike controls who still had a high level of coexpression. To ensure the loss of $T H$ was specific to Kiss 1 cells, we also counted and compared the number of non-Kiss1 TH cells in the AVPV/PeN between WT and Kiss THKO mice $(50-60 \%$ of all TH cells in the AVPV/PeN do not coexpress kisspeptin and are a distinct population separate from the Kiss1 cells in this region; Semaan et al., 2010).

\section{Puberty onset and fertility measures}

Beginning at postnatal day (PND) 21, male and female Kiss THKO and WT littermates ( $n=6-9 /$ sex/genotype) were checked daily for preputial separation, a pubertal marker in males, or vaginal opening (VO), a midstage pubertal marker in females. Following VO, females were checked daily for first estrus (FE, a sign of first ovulatory event, a later pubertal event) based on vaginal smears.

To assess fertility, at eight weeks of age, male and female Kiss THKO mice and WT littermates $(n=5-8 / \mathrm{sex} /$ genotype) were set up with age-matched C57BL6 breeder partners for eight weeks. During those eight weeks, breeding pairs were examined daily to check for new litters, and the number of pups in each litter was counted on the day of birth. After eight weeks, the breeding pairs were separated and the breeder females were monitored for any new litters for an additional three weeks (i.e., a total of 11 weeks since the initial breeder pairing). We then calculated the percentage of mice having litters, the latency to first litter, the total number of litters, the total number of pups, and the mean number of pups/litter.

\section{Basal gonadotropin measurements and the $E_{2}$-induced LH surge}

To assess basal gonadotropin levels, a blood sample was collected at eight weeks of age from gonad-intact males and females (diestrus) of both genotypes ( $n=$ 13-15/genotype/sex). Blood serum was sent to the Ligand Assay Core at the University of Virginia to measure LH and FSH (both sexes), as well as testosterone (T) levels (males). LH and FSH levels were quantified using a mouse multiplex assay with a detection limit of $0.24 \mathrm{ng} / \mathrm{ml}$ for $\mathrm{LH}$ and $2.4 \mathrm{ng} / \mathrm{ml}$ for FSH. T levels were measured using an ELISA assay with a lower detection limit of $10 \mathrm{ng} / \mathrm{dL}$.

In a separate cohort of eight-week-old adult female mice, we used a well-established estrogen-positive feedback paradigm (Stephens et al., 2015; Luo et al., 2016) to examine the $\mathrm{E}_{2}$-induction of the circadian-timed LH surge. Briefly, females were OVX and given $E_{2}$ SILASTIC implants, which produce constant proestrus-like levels of $E_{2}$ (Dror et al., 2013). Females were then sacrificed two days later, either in the morning at 10 A.M. ( $n=4-5 /$ genotype) or in the evening at 5:45 P.M., just before lights off ( $n=$ 9-11/genotype). In mice, the $E_{2}$-induced LH surge occurs only in the evening, around the time of lights off (Robertson et al., 2009). Brains were collected, immediately frozen on dry ice, and stored at $-80^{\circ} \mathrm{C}$ before being sectioned on a cryostat in $20-\mu \mathrm{m}$ sections. Brain sections were mounted on Superfrost-plus slides in five alternating sets and stored at $-80^{\circ} \mathrm{C}$ until being used for $\mathrm{ISH}$. Blood was also collected at sacrifice and blood serum assayed for LH using a sensitive LH RIA (lower detection limit of $0.04 \mathrm{ng} / \mathrm{ml}$ ) at the Ligand Assay Core at the University of Virginia.

\section{Longitudinal body weights and gonad tissue collections}

Body weights in gonad-intact mice were measured every three weeks, from 3 to 24 weeks of age, to ensure there were no genotype differences in body weight that may affect fertility ( $n=4-6 /$ sex/genotype).

In a separate cohort of adult WT and Kiss THKO mice ( $n$ $=4-8 /$ sex/genotype), gonads were collected at eight weeks of age. Gonads were immediately weighed; the ovaries were then fixed in $4 \%$ paraformaldehyde, embed- 
ded in paraffin, and cut in $10-\mu \mathrm{m}$ sections on a microtome. Ovary slices were then mounted onto slides and stained with hematoxylin and eosin to permit the counting of the number of corpora lutea (a marker of ovulation) for each ovary ( $n=6-7 /$ genotype).

\section{Single- and double-label ISH}

Using an established radio-labeled $\left({ }^{33} \mathrm{P}\right)$ antisense mouse Kiss 1 riboprobe $(0.04 \mathrm{pmol} / \mathrm{ml})$, Kiss 1 levels in the AVPV/PeN were assayed in females (eight weeks old) via single-label ISH, using one of the five sets of brain sections, as previously described (Kim et al., 2013; Di Giorgio et al., 2014; Stephens et al., 2015, 2016). In separate sets of brain sections, double-label ISH analysis was also completed to (1) quantify the degree of TH and Kiss1 coexpression in the AVPV/PeN; and (2) analyze neuronal activation in Kiss 1 and $\mathrm{GnRH}$ cells during the $\mathrm{LH}$ surge, using a cfos mRNA induction as an indicator of neuronal activation. Double-label ISH analysis was performed as previously described by combining a radio-labeled $\left({ }^{33} \mathrm{P}\right)$ $\mathrm{TH}$ or cfos probe $(0.04 \mathrm{pmol} / \mathrm{ml})$ and digoxygenin-labeled (DIG) Kiss 1 or $\mathrm{GnRH}$ riboprobe (1:500) before application to each slide (Dror et al., 2013; Semaan and Kauffman, 2015; Stephens et al., 2015). Microscopy analysis of ISH slides was completed by an observer "blind" to treatment group through the use of an automated silver grains imaging processing system (Dr. Don Clifton, University of Washington). The computer program counts the number of cells, represented as silver grain clusters, as well as the number of silver grains in each cell, representing a semiquantitative measure of mRNA content per cell (Chowen et al., 1990). For double-label ISH analysis, DIG cells (Kiss1 or $\mathrm{GnRH}$ ) were identified and outlined using fluorescence microscopy and the grain counting software quantified the number of silver grains (cfos or TH mRNA) within those cells. Signal-to-background ratios were then calculated for each cell, and cells were considered to be double-labeled if the signal-to-background ratio was $>4$.

\section{Statistical analysis}

All data are expressed as the mean \pm SEM for each group. Unpaired $t$-tests were used for all puberty onset, basal gonadotropin, gonadal weight, and fertility analyses. Body weight was analyzed using a repeatedmeasures ANOVA. LH levels during the A.M. and P.M. on the day of the $\mathrm{LH}$ surge and quantitative ISH measures were analyzed using a two-way ANOVA and Bonferroni post hoc tests. Statistical significance was reached if $p<$ 0.05 .

\section{Results}

\section{Verification of conditional deletion of TH from Kiss 1 cells}

Using Cre/lox technology, we selectively removed $\mathrm{TH}$ only from Kiss 1 cells. Confirming proper excision of the TH gene in Kiss1 cells, Cre-mediated recombination of the $\mathrm{TH}$ gene was detected in several tissues from Kiss THKO mice, specifically in the ARC, AVPV/PeN, MeA, liver, and gonads (all tissues known to normally express Kiss1; Fig. 1D). Tissues known to not express Kiss1, such as cerebellum, tail, and spleen, did not show recombination of $\mathrm{TH}$, indicating that recombination was specific to Kiss1-expressing cells. To further confirm the conditional knock-out and quantify the degree of $\mathrm{TH}$ ablation from Kiss1 cells, we performed double-label ISH for $\mathrm{TH}$ and Kiss 1 coexpression in the AVPV/PeN brain region. As expected, WT females showed a very high degree of TH/Kiss 1 colocalization in the AVPV/PeN, with nearly $90 \%$ of their Kiss1 neurons coexpressing TH mRNA. In contrast, Kiss THKO females showed virtually no colocalization of $\mathrm{TH}$ in Kiss 1 cells in the AVPV/PeN $(<3 \% ; p<0.05$ vs controls; Fig. 1E). To ensure the loss of TH was specific to just kisspeptin cells, we also counted and compared the number of non-Kiss $1 \mathrm{TH}$ cells in the AVPV/PeN (since approximately half of all the $\mathrm{TH}$ cells in this region are a separate cell population from the Kiss1 cells). We found no difference between WT and Kiss THKO mice in the number of non-Kiss $1 \mathrm{TH}$ cells in the AVPV/PeN $(231 \pm 20$ and $249 \pm 13$, respectively, $p=0.49$ ), indicating the loss of $\mathrm{TH}$ was specific to Kiss 1 cells.

\section{Puberty onset and body weights}

Because dopamine can inhibit $\mathrm{GnRH}$ neurons and puberty onset is governed by $\mathrm{GnRH}$ release, we first examined if puberty onset in Kiss THKO mice was altered. For females, neither the timing of VO (midstage pubertal marker) nor FE (late pubertal marker) differed between WT and Kiss THKO mice (Fig. $2 A, B$ and $C, D$, respectively). In males, the pubertal marker of preputial separation was similarly not altered in Kiss THKOs and occurred at a comparable age to controls (Fig. 2E,F). Body weights did not differ between WT and Kiss THKO mice of either sex throughout puberty (data not shown), nor did BWs differ throughout development and adulthood (Fig. 2G,H).

\section{Reproductive hormones and gonad weights}

Basal LH and FSH levels were comparable between adult WT and Kiss THKO females (all measures from diestrus stage), although there was a nonsignificant trend $(p=0.08)$ for higher FSH levels in Kiss THKO females (Fig. $3 A, B)$. Ovarian weights also did not differ between WT and Kiss THKO females (Fig. 3C,D). Kiss THKO males showed a similar outcome as Kiss THKO females, with no significant difference in basal LH levels in comparison to WT littermates males, but a nonsignificant trend for higher basal FSH levels (Fig. 4A,B). Despite no differences in circulating $\mathrm{LH}$ and $\mathrm{FSH}$, Kiss THKO males did have significantly higher circulating serum $\mathrm{T}$ levels (Fig. $4 C ; p=$ 0.03 ); however, testes weight was normal and did not differ between WT and Kiss THKO males (Fig. 4D).

\section{LH surge and ovulation}

$\mathrm{TH}$ is highly coexpressed with AVPV/PeN Kiss1 neurons, a neural population that mediates $\mathrm{E}_{2}$-positive feedback in females to generate the $\mathrm{GnRH} / \mathrm{LH}$ surge, thereby triggering ovulation. We hypothesized that dopamine produced in these kisspeptin cells may therefore influence the LH surge and ovulation. Using a well-established daily $\mathrm{E}_{2}$-induced $\mathrm{LH}$ surge paradigm, we found that a similar percentage of OVX $+E_{2}$ WT and Kiss THKO females 
A

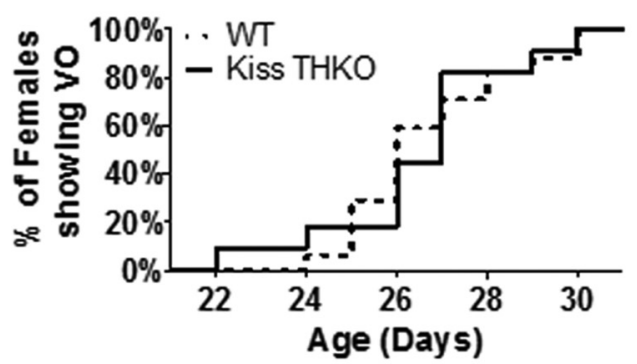

C

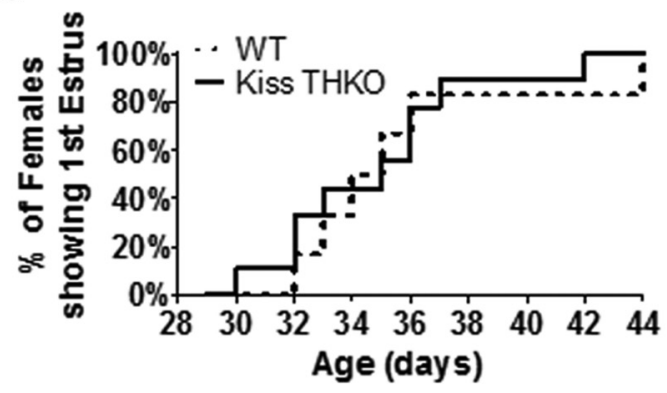

E

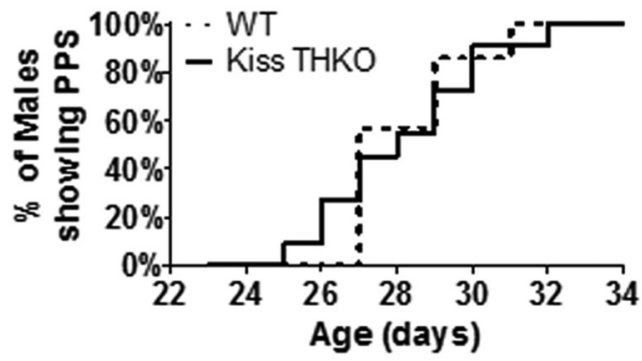

G

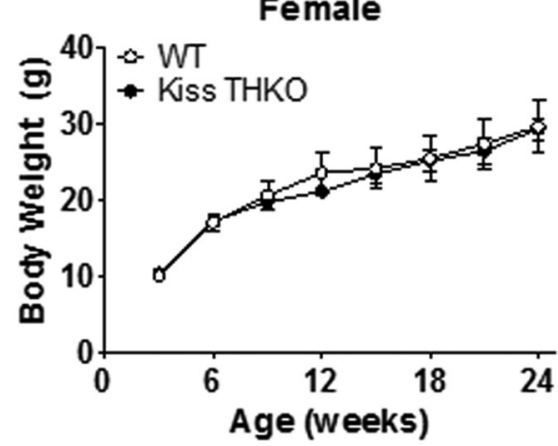

B

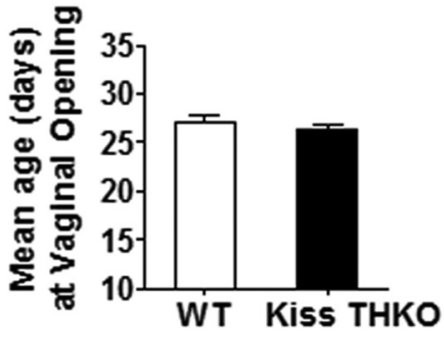

D

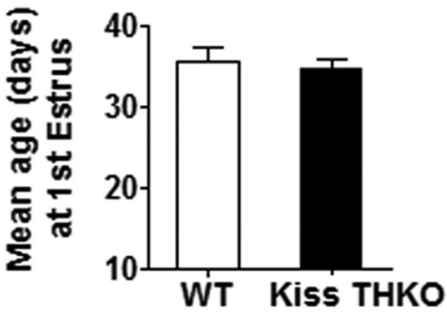

$F$

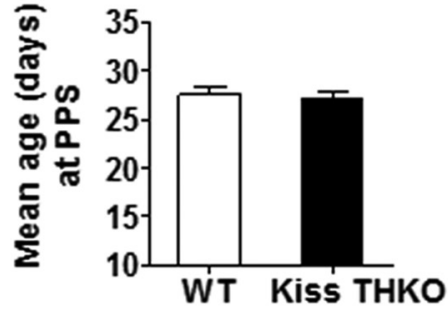

H Male

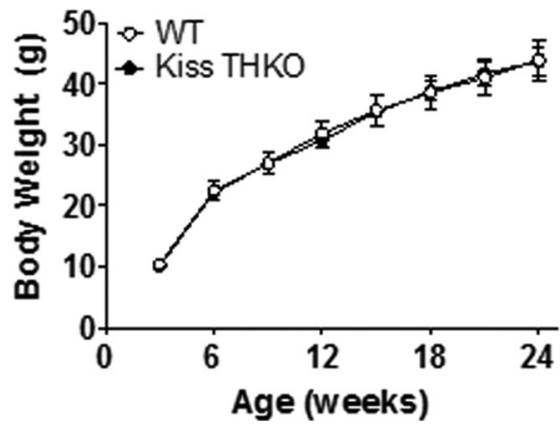

Figure 2. Removal of $T H$ selectively from just Kiss1 neurons does not alter the timing of puberty onset. $\boldsymbol{A}$, Percentage of females experiencing VO from PND 22 to PND 31. B. Mean age at VO in females. $\boldsymbol{C}$, Percentage of females experiencing FE from PND 30 to PND 44. D, Mean age at FE in females. $\boldsymbol{E}$, Percentage of males experiencing preputial separation (PPS) from PND 22 to PND 34 . $\boldsymbol{F}$, Mean age at PPS in males ( $n=6-9 /$ genotype). $\boldsymbol{G}, \boldsymbol{H}$, Body weight throughout development and adulthood did not differ between WT and Kiss THKO females (G) and males $(\boldsymbol{H} ; n=4-6 /$ genotype).

generated an LH surge (Fig. 5A). Both genotypes had very low $\mathrm{LH}$ levels in the morning, as expected due to the circadian nature of the LH surge, but had similarly elevated $\mathrm{LH}$ levels in the evening, indicative of $\mathrm{LH}$ surges (Fig. $5 B$ ). The number of corpora lutea in the ovaries, indicative of ovulatory events, did not differ between WT and Kiss THKO mice (Fig. 5C,D).

We performed single-label ISH for Kiss1 in the AVPV/ $\mathrm{PeN}$ to ensure that removal of $T H$ from Kiss 1 cells did not alter AVPV/PeN Kiss1 expression. The number of AVPV/ 
A

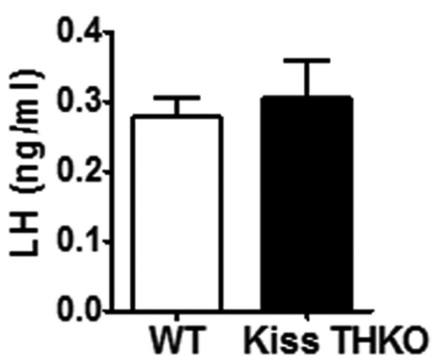

B

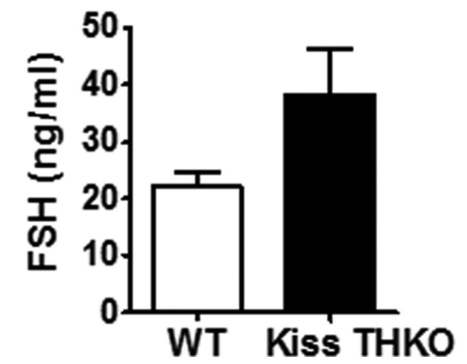

C ิิ

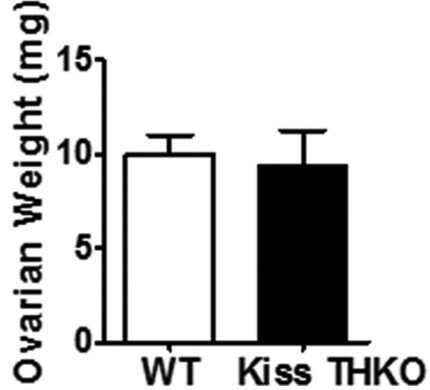

Figure 3. Basal gonadotropin levels and ovarian weights in females did not differ. LH $(\boldsymbol{A})$ and FSH $(\boldsymbol{B} ; n=13 / g e n o t y p e)$ as well as ovarian weights ( $\boldsymbol{C} ; n=6-8 /$ genotype) did not differ between eight-week-old WT and Kiss THKO females.

PeN Kiss1 cells in WT and Kiss THKO mice did not significantly differ (Fig. 6A,B). Neuronal activation, measured by cfos coexpression, of Kiss1 cells in the AVPV/ $\mathrm{PeN}$ was significantly greater during the LH surge (P.M.) in comparison to the A.M. $(p<0.001)$ and did not differ between WT and Kiss THKO mice at either time point (Fig. $6 C, D)$. Similarly, $\mathrm{GnRH}$ neuronal activation, measured by cfos induction in $\mathrm{GnRH}$ cells, was significantly greater in the evening than in the morning for both WT and Kiss THKO females $(p<0.001)$, with a similar magnitude of cfos coexpression for the two genotypes (Fig. $6 E, F$ ).

\section{Fertility and fecundity}

Because of dopamine's inhibitory actions on $\mathrm{GnRH}$, we hypothesized that removal of TH from Kiss 1 cells would lower inhibition on $\mathrm{GnRH}$ neurons and thereby enhance specific parameters of fertility and/or fecundity (e.g., time to producing litters, total numbers of litters generated, number of pups per litter). We found that Kiss THKO mice of both sexes were completely fertile. In females, there were no significant genotype differences in the percentage of females giving birth, the latency to first litter, the total number of litters, and the mean number of pups/litter between WT and Kiss THKO mice (Fig. 7A-D), indicating fertility and fecundity were not enhanced in Kiss THKO females. Males showed a similar outcome, with no alterations in any fertility or fecundity measures in Kiss THKO mice (Fig. 7E-H).

\section{Discussion}

Kisspeptin regulates puberty and reproduction by directly stimulating the release of GnRH. Kisspeptin neurons in the AVPV/PeN are sexually dimorphic and participate in $\mathrm{E}_{2}$-mediated positive feedback and the preovulatory LH surge. The vast majority of kisspeptin cells in the AVPV/PeN express TH mRNA and protein (Semaan et al., 2010; Clarkson and Herbison, 2011), which suggests that dopamine, like kisspeptin, in the AVPV/PeN may be important for governing GnRH secretion and perhaps participating in $E_{2}$-positive feedback. To test this
A

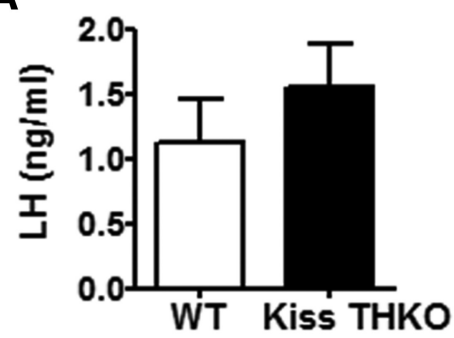

C

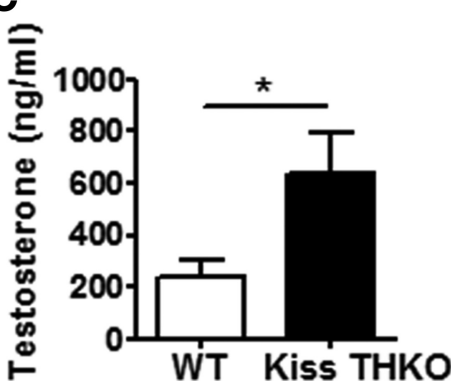

B

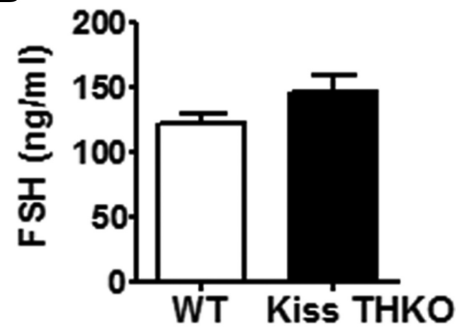

D

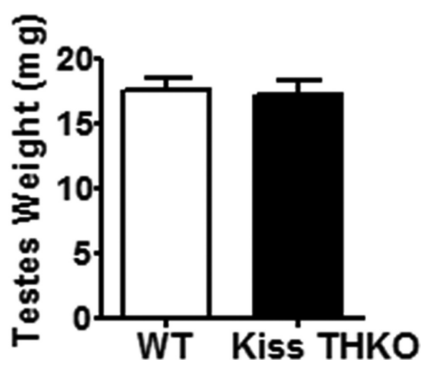

Figure 4. Basal hormone levels and testes weights in eight-week-old WT and Kiss THKO male mice. LH (A) and FSH (B) did not differ between WT and Kiss THKO males ( $n=13-15 /$ genotype). T $(\boldsymbol{C})$ levels were significantly higher in Kiss THKO males $(* p<0.05 ; n=$ 13-15/genotype). However, testes weights $(\boldsymbol{D})$ did not significantly differ between WT and Kiss THKO males $(n=6-8 /$ genotype). 
A

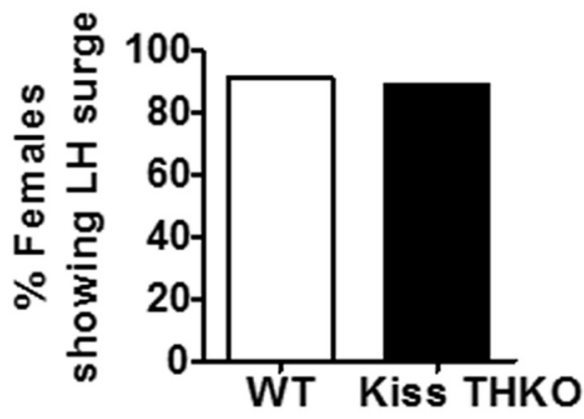

B

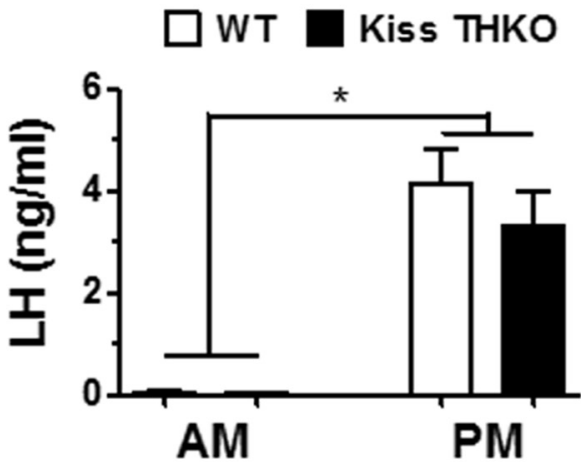

C

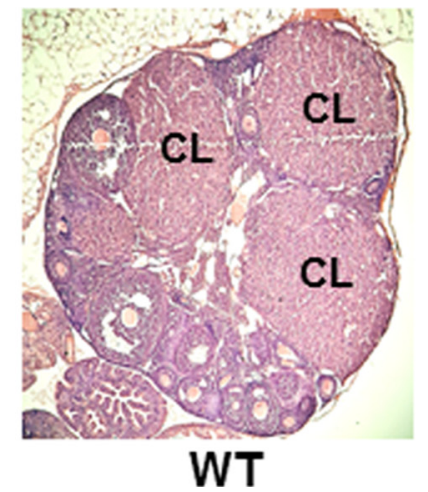

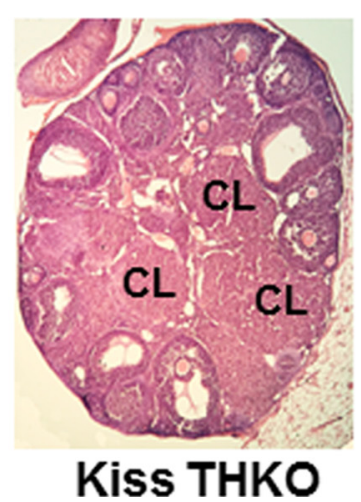

D

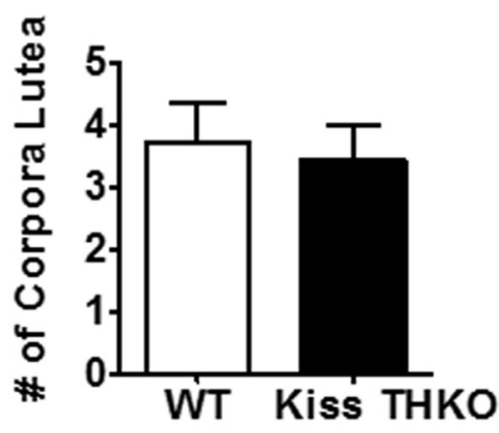

Figure 5. The $\mathrm{E}_{2}$-mediated LH surge was not altered in Kiss THKO females. $\boldsymbol{A}$, Percentage of eight-week-old females having an $\mathrm{E}_{2}$-mediated LH surge did not differ between WT and Kiss THKOs ( $n=9-11 /$ genotype). $\boldsymbol{B}$, Neither genotype experienced an LH surge in the morning ( $n=4-5 /$ genotype), but both WT and Kiss THKOs had similar LH levels during the PM LH surge ( $n=9-11 /$ genotype). $\boldsymbol{C}, \boldsymbol{D}$, The number of corpora lutea did not differ between genotypes at eight weeks of age $(n=6 / g e n o t y p e)$. $*$, significant main effect of time, $p<0.05$

possibility, we used Cre-lox technology to selectively ablate $T H$ from Kiss 1 cells. Surprisingly, despite a practically complete knock-out of $T H$ from Kiss 1 cells, we found that all aspects of puberty, reproductive hormone secretion, and fertility were normal in Kiss THKOs. This suggests that dopamine synthesized in Kiss 1 cells is not required for normal puberty and reproduction.

Because (1) dopamine inhibits $\mathrm{GnRH}$ neurons (Liu and Herbison, 2013), (2) TH and Kiss1 are highly colocalized in the AVPV/PeN (Semaan et al., 2010), and (3) kisspeptin neurons in the AVPV/PeN regulate $E_{2}$-positive feedback (Smith et al., 2006; Robertson et al., 2009), we hypothesized that puberty completion may be accelerated and fertility/fecundity may be enhanced, primarily in females since males have a much smaller Kiss 1/TH population (Kauffman et al., 2007; Semaan et al., 2010). Surprisingly, despite a virtually complete ablation of $T H$ levels in Kiss 1 cells, puberty measures were comparable between WT and Kiss THKO mice in both sexes. Puberty onset is initiated by an increase in pulsatile $\mathrm{GnRH}$ and $\mathrm{LH}$ release, and most studies have implicated ARC kisspeptin neurons, rather than AVPV/PeN kisspeptin neurons, in the regulation of pulsatile $\mathrm{GnRH}$ release. Thus, it would stand to reason that altering AVPV/PeN but not ARC kisspeptin neurons would not dramatically impact puberty onset. However, puberty completion in females is dependent on achieving first ovulation (measured by FE), and this would be dependent on proper AVPV/PeN kisspeptin neuron function underlying the LH surge process. Despite this, we found that FE in females lacking dopamine in AVPV/ $\mathrm{PeN}$ kisspeptin neurons occurred at a normal age and was not hastened.

As with puberty, we were surprised to find that fertility and fecundity measures were completely normal in Kiss THKO mice of both sexes. We found no differences in basal circulating gonadotropin levels, multiple fertility measures, or the induction and magnitude of an LH surge between adult WT and Kiss THKO females. This indicates that $T H$ (i.e., dopamine) in AVPV/PeN Kiss1 cells is not required for male or female reproduction and proper regulation of the reproductive neuroendocrine axis. Our findings support recent data showing that ablation of a majority (75\%) of all AVPV TH cells, not just TH in Kiss1 cells, had no effect on estrous cycles or female reproductive success (male fertility not studied; Scott et al., 2015). However, the percentage of AVPV kisspeptin cells that remained in that study was not determined, and it is highly possible that enough kisspeptin cells (perhaps also 25\% like the TH cells) remained to sustain female reproduction.

Because AVPV/PeN TH and Kiss1 expression levels are markedly lower in males, and male reproduction is likely regulated primarily by ARC kisspeptin neurons (which do not coexpress TH; Szawka et al., 2010), we hypothesized that puberty onset and fertility would be similar in WT and 
A
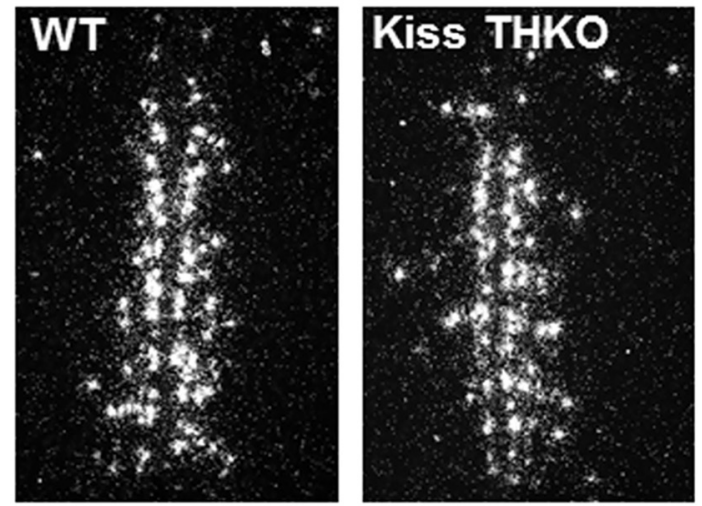

C
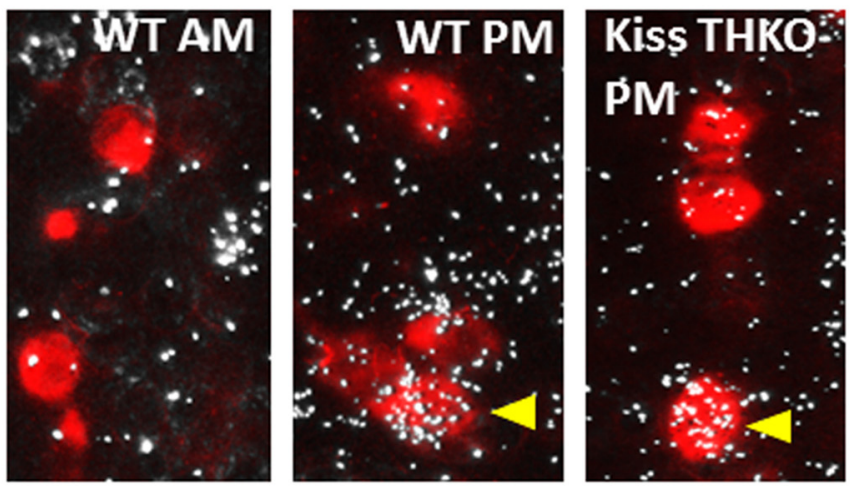

D

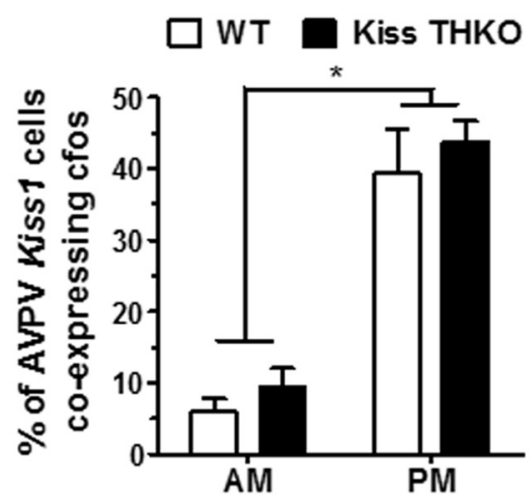

E
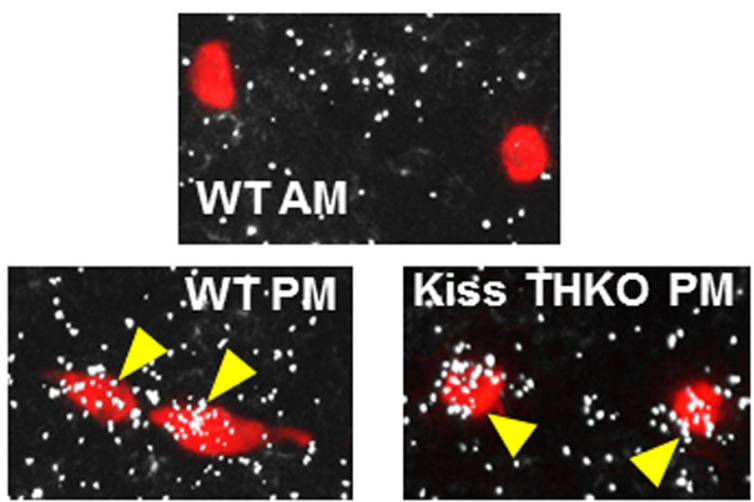

B

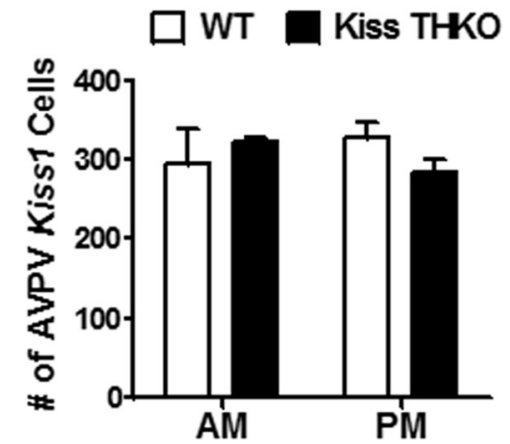

Figure 6. Kiss1 as well as cfos expression in Kiss1 and GnRH cells at the time of the $\mathrm{E}_{2}$-mediated LH surge did not differ between WT and Kiss THKO females. A, Photomicrograph of Kiss1 (silver grains) expression in the AVPV of adult WT and Kiss THKO female mice. B, Kiss1 levels in the AVPV/PeN of females did not differ between WT and Kiss THKOs. C, ISH photomicrograph of cfos (silver grains), a measure of gene activation, and Kiss1 (red fluorescence) colocalization (indicated by yellow arrows) in the AVPV/PeN of adult female mice in the PM (at the time of the LH surge). D, cfos expression in Kiss1 cells was low in the A.M. and elevated in the P.M. in both WT and Kiss THKOs. E, Photomicrograph of cfos (silver grains) and GnRH (red fluorescence) coexpression (indicated by yellow arrows) in the OVLT of adult female WT and Kiss THKO mice. $\boldsymbol{F}$, cfos expression in GnRH cells was low in the A.M. and elevated in the P.M. (at the time of the LH surge) in both WT and Kiss THKOs. *, significant main effect of time, $p<0.05$.

Kiss THKO males. Indeed, as in females, puberty onset, basal gonadotropin, and fertility were all normal in Kiss THKO males. However, despite comparable LH and FSH levels and normal testes weights, circulating $T$ levels were significantly higher in Kiss THKO males. Since this in- crease in T was not accompanied by higher gonadotropin levels, we speculate that this represents an effect occurring specifically within the testes. The testes express both kisspeptin and TH (Frungieri et al., 2000; Davidoff et al., 2005; Anjum et al., 2012), and as such, TH/dopamine may 
A

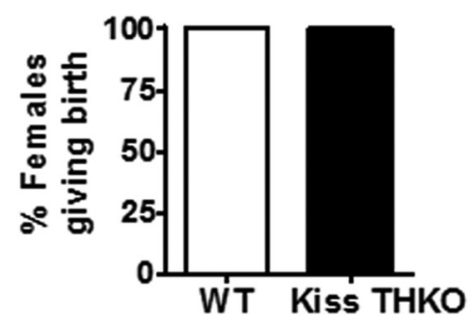

C

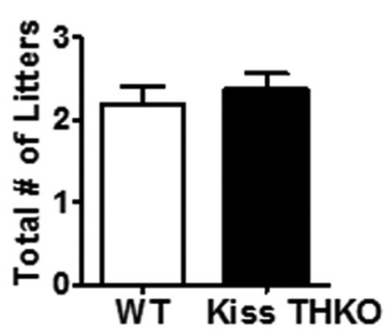

E

G

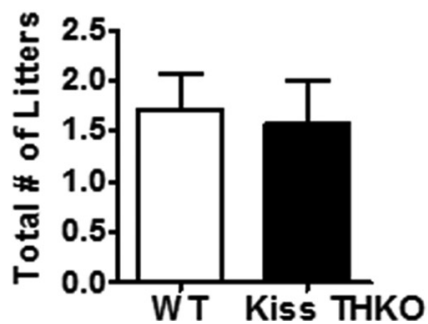

B

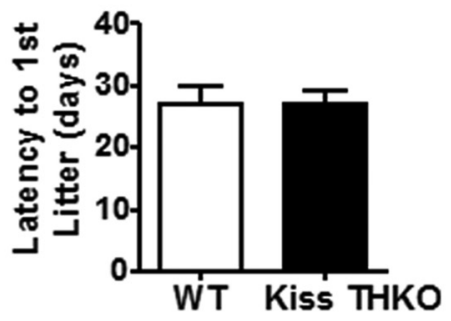

D

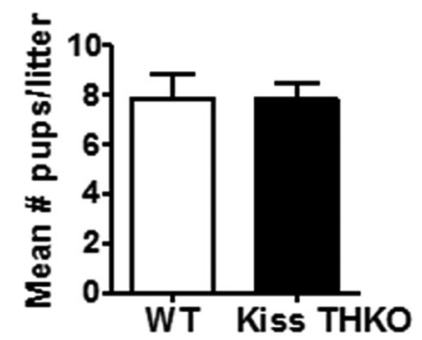

F

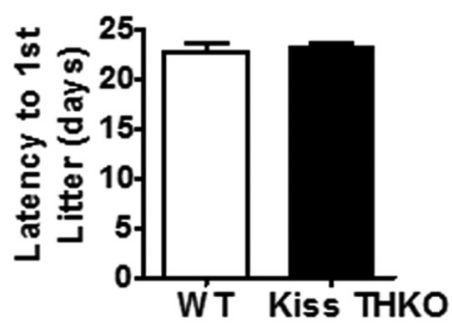

H

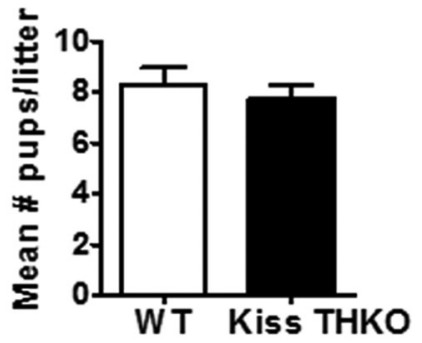

Figure 7. $\mathrm{TH}$ in Kiss1 cells is not required for normal fertility in females $(\boldsymbol{A}-\mathbf{-} \boldsymbol{D})$ or males $(\boldsymbol{E}-\mathbf{-} \boldsymbol{H})$. $\boldsymbol{A}$, Percentage of WT and Kiss THKO females that had a litter during the 11-week fertility assessment. $\boldsymbol{B}$, Mean latency (days) to first litter after pairing with the male. $\boldsymbol{C}$, Mean total number of litters during the 11-week fertility study. $\boldsymbol{D}$, Mean number of pups/litter $(n=5-8 /$ genotype). $\boldsymbol{E}$, Percentage of males siring at least one litter during the 11-week fertility assessment ( $n=7 /$ genotype). $\boldsymbol{F}$, Mean latency (days) between the initial pairing with the female and when the first litter was born; measure only includes males that sired a litter. Mean total number of litters each male sired $(\boldsymbol{G})$ and the mean number of pups/litter $(\boldsymbol{H})$.

be significantly ablated within testicular cells (though it is unknown if kisspeptin and TH are in the same testis cell types). It is possible that such a decrease in local dopamine may alter testicular $T$ synthesis, although this remains to be tested in future studies. Regardless, there was no significant difference in any fertility measure between WT and Kiss THKO males, suggesting that the elevated $\mathrm{T}$ did not enhance reproduction in the latter group.

Most AVPV/PeN Kiss1 cells coexpress TH (Semaan et al., 2010), yet our present data indicate that $T H$, and hence, dopamine, in Kiss 1 cells is not required for proper regulation of puberty and fertility in females and males. Thus, the function of dopamine signaling arising from 
Kiss 1 cells currently remains unknown. Recent data suggests that some AVPV TH neurons project to the PVN and activate oxytocin neurons, thereby increasing oxytocin secretion (Seymour et al., 2017). This AVPV TH neuron to PVN oxytocin circuit may play a role in maternal behavior and/or lactation (Scott et al., 2015; Seymour et al., 2017). Thus, it is possible that dopamine in AVPV/PeN Kiss 1 cells is involved in oxytocin release or plays a role in regulating maternal behavior. However, our Kiss THKO females successfully carried full pregnancies, had normal parturition times, and normal litter sizes, suggestion oxytocin was likely unaffected. Future research is needed to directly evaluate this hypothesis and to further examine additional functions of dopamine coexpressed in Kiss 1 cells.

\section{References}

Anjum S, Krishna A, Sridaran R, Tsutsui K (2012) Localization of gonadotropin-releasing hormone $(\mathrm{GnRH})$, gonadotropin-inhibitory hormone $(\mathrm{GnlH})$, kisspeptin and $\mathrm{GnRH}$ receptor and their possible roles in testicular activities from birth to senescence in mice. J Exp Zool A Ecol Genet Physiol 317:630-644. CrossRef Medline

Chowen JA, Argente J, Vician L, Clifton DK, Steiner RA (1990) Pro-opiomelanocortin messenger RNA in hypothalamic neurons is increased by testosterone through aromatization to estradiol. Neuroendocrinology 52:581-588. Medline

Clarkson J, Herbison AE (2006) Postnatal development of kisspeptin neurons in mouse hypothalamus; sexual dimorphism and projections to gonadotropin-releasing hormone neurons. Endocrinology 147:5817-5825. CrossRef Medline

Clarkson J, Herbison AE (2011) Dual phenotype kisspeptindopamine neurones of the rostral periventricular area of the third ventricle project to gonadotrophin-releasing hormone neurones. J Neuroendocrinol 23:293-301. CrossRef Medline

Clarkson J, d'Anglemont de Tassigny X, Moreno AS, Colledge WH, Herbison AE (2008) Kisspeptin-GPR54 signaling is essential for preovulatory gonadotropin-releasing hormone neuron activation and the luteinizing hormone surge. J Neurosci 28:8691-8697. CrossRef

d'Anglemont de Tassigny X, Fagg LA, Carlton MB, Colledge WH (2008) Kisspeptin can stimulate gonadotropin-releasing hormone $(\mathrm{GnRH})$ release by a direct action at $\mathrm{GnRH}$ nerve terminals. Endocrinology 149:3926-3932.

Davidoff MS, Ungefroren H, Middendorff R, Koeva Y, Bakalska M, Atanassova N, Holstein AF, Jezek D, Pusch W, Müller D (2005) Catecholamine-synthesizing enzymes in the adult and prenatal human testis. Histochem Cell Biol 124:313-323. CrossRef Medline

de Roux N, Genin E, Carel JC, Matsuda F, Chaussain JL, Milgrom E (2003) Hypogonadotropic hypogonadism due to loss of function of the KiSS1-derived peptide receptor GPR54. Proc Natl Acad Sci USA 100:10972-10976. CrossRef Medline

Di Giorgio NP, Semaan SJ, Kim J, López PV, Bettler B, Libertun C, Lux-Lantos VA, Kauffman AS (2014) Impaired GABAB receptor signaling dramatically up-regulates Kiss 1 expression selectively in nonhypothalamic brain regions of adult but not prepubertal mice. Endocrinology 155:1033-1044. CrossRef

Dror T, Franks J, Kauffman AS (2013) Analysis of multiple positive feedback paradigms demonstrates a complete absence of LH surges and $\mathrm{GnRH}$ activation in mice lacking kisspeptin signaling. Biol Reprod 88:146. CrossRef Medline

Frungieri MB, Urbanski HF, Höhne-Zell B, Mayerhofer A (2000) Neuronal elements in the testis of the rhesus monkey: ontogeny, characterization and relationship to testicular cells. Neuroendocrinology 71:43-50. Medline

Gottsch ML, Cunningham MJ, Smith JT, Popa SM, Acohido BV, Crowley WF, Seminara S, Clifton DK, Steiner RA (2004) A role for kisspeptins in the regulation of gonadotropin secretion in the mouse. Endocrinology 145:4073-4077. CrossRef Medline

Jarjour LT, Handelsman DJ, Raum WJ, Swerdloff RS (1986) Mechanism of action of dopamine on the in vitro release of gonadotropin-releasing hormone. Endocrinology 119:1726-1732. CrossRef Medline

Kauffman AS, Gottsch ML, Roa J, Byquist AC, Crown A, Clifton DK, Hoffman GE, Steiner RA, Tena-Sempere M (2007) Sexual differentiation of Kiss1 gene expression in the brain of the rat. Endocrinology 148:1774-1783. CrossRef Medline

Kim J, Tolson KP, Dhamija S, Kauffman AS (2013) Developmental $\mathrm{GnRH}$ signaling is not required for sexual differentiation of kisspeptin neurons but is needed for maximal Kiss1 gene expression in adult females. Endocrinology 154:3273-3283. CrossRef

Kumar D, Candlish M, Periasamy V, Avcu N, Mayer C, Boehm U (2015) Specialized subpopulations of kisspeptin neurons communicate with $\mathrm{GnRH}$ neurons in female mice. Endocrinology 156:3238. CrossRef Medline

Lapatto R, Pallais JC, Zhang D, Chan YM, Mahan A, Cerrato F, Le WW, Hoffman GE, Seminara SB (2007) Kiss1-/- mice exhibit more variable hypogonadism than Gpr54-/- mice. Endocrinology 148: 4927-4936. CrossRef Medline

Liu X, Herbison AE (2013) Dopamine regulation of gonadotropinreleasing hormone neuron excitability in male and female mice. Endocrinology 154:340-350. CrossRef Medline

Luo E, Stephens SB, Chaing S, Munaganuru N, Kauffman AS, Breen KM (2016) Corticosterone blocks ovarian cyclicity and the LH surge via decreased kisspeptin neuron activation in female mice. Endocrinology 157:1187-1199. CrossRef Medline

Robertson JL, Clifton DK, de la Iglesia HO, Steiner RA, Kauffman AS (2009) Circadian regulation of Kiss1 neurons: implications for timing the preovulatory gonadotropin-releasing hormone/luteinizing hormone surge. Endocrinology 150:3664-3671. CrossRef Medline

Rotsztejn WH, Charli JL, Pattou E, Kordon C (1977) Stimulation by dopamine of luteinizing hormone-releasing hormone (LHRH) release from the mediobasal hypothalamus in male rats. Endocrinology 101:1475-1483. CrossRef Medline

Sarkar DK, Fink G (1981) Gonadotropin-releasing hormone surge: possible modulation through postsynaptic alpha-adrenoreceptors and two pharmacologically distinct dopamine receptors. Endocrinology 108:862-867. CrossRef Medline

Scott N, Prigge M, Yizhar O, Kimchi T (2015) A sexually dimorphic hypothalamic circuit controls maternal care and oxytocin secretion. Nature 525:519-522. CrossRef Medline

Semaan SJ, Kauffman AS (2015) Daily successive changes in reproductive gene expression and neuronal activation in the brains of pubertal female mice. Mol Cell Endocrinol 401:84-97. CrossRef Medline

Semaan SJ, Murray EK, Poling MC, Dhamija S, Forger NG, Kauffman AS (2010) BAX-dependent and BAX-independent regulation of Kiss1 neuron development in mice. Endocrinology 151:58075817. CrossRef Medline

Seminara SB, Messager S, Chatzidaki EE, Thresher RR, Acierno JS Jr, Shagoury JK, Bo-Abbas Y, Kuohung W, Schwinof KM, Hendrick AG, Zahn D, Dixon J, Kaiser UB, Slaugenhaupt SA, Gusella JF, O'Rahilly S, Carlton MB, Crowley WF Jr, Aparicio SA, Colledge WH (2003) The GPR54 gene as a regulator of puberty. N Engl J Med 349:1614-1627. CrossRef Medline

Seymour AJ, Scott V, Augustine RA, Bouwer GT, Campbell RE, Brown CH (2017) Development of an excitatory kisspeptin projection to the oxytocin system in late pregnancy. J Physiol 595:825838. CrossRef Medline

Simerly RB, Swanson LW, Gorski RA (1985) The distribution of monoaminergic cells and fibers in a periventricular preoptic nucleus involved in the control of gonadotropin release: immunohistochemical evidence for a dopaminergic sexual dimorphism. Brain Res 330:55-64. CrossRef

Smith JT, Cunningham MJ, Rissman EF, Clifton DK, Steiner RA (2005a) Regulation of Kiss1 gene expression in the brain of the female mouse. Endocrinology 146:3686-3692. 
Smith JT, Dungan HM, Stoll EA, Gottsch ML, Braun RE, Eacker SM, Clifton DK, Steiner RA (2005b) Differential regulation of KiSS-1 mRNA expression by sex steroids in the brain of the male mouse. Endocrinology 146:2976-2984.

Smith JT, Popa SM, Clifton DK, Hoffman GE, Steiner RA (2006) Kiss1 neurons in the forebrain as central processors for generating the preovulatory luteinizing hormone surge. J Neurosci 26:6687-6694. CrossRef

Stephens SB, Tolson KP, Rouse ML Jr, Poling MC, HashimotoPartyka MK, Mellon PL, Kauffman AS (2015) Absent progesterone signaling in kisspeptin neurons disrupts the LH surge and impairs fertility in female mice. Endocrinology 156:3091-3097. CrossRef
Stephens SB, Chahal N, Munaganuru N, Parra RA, Kauffman AS (2016) Estrogen stimulation of Kiss1 expression in the medial amygdala involves estrogen receptor- $\alpha$ but not estrogen receptor- $\beta$. Endocrinology 157:4021-4031. CrossRef

Szawka RE, Ribeiro AB, Leite CM, Helena CV, Franci CR, Anderson GM, Hoffman GE, Anselmo-Franci JA (2010) Kisspeptin regulates prolactin release through hypothalamic dopaminergic neurons. Endocrinology 151:3247-3257. CrossRef Medline

Topaloglu AK, Tello JA, Kotan LD, Ozbek MN, Yilmaz MB, Erdogan S, Gurbuz F, Temiz F, Millar RP, Yuksel B (2012) Inactivating KISS1 mutation and hypogonadotropic hypogonadism. N Engl J Med 366:629-635. CrossRef Medline 